\title{
Association between HLA-A, HLA-C and HLA-B Genes and Ankylosing Spondylitis in Macedonian Population
}

\author{
Meri Kirijas ${ }^{1}$, Snezhana Mishevska-Perchinkova ${ }^{2}$, Anzelika Karadzova-Stojanoska², Olivija Efinska-Mladenovska ${ }^{1}$, Aleksandar \\ Petlichkovski ${ }^{1}$, Dejan Trajkov ${ }^{1}$, Mirko Spiroski ${ }^{1}$ \\ ${ }^{1}$ Institute of Immunobiology and Human Genetics, Faculty of Medicine, University "Ss. Cyril and Methodius", Skopje, Republic of Macedonia; \\ 2University Clinic of Rheumatology, Faculty of Medicine, University "Ss. Cyril and Methodius", Skopje, Republic of Macedonia
}

\begin{abstract}
Citation: Kirijas M, Mishevska-Perchinkova S, Karadzova-Stojanoska A, Efinska-Mladenovska O, Petlichkovski A, Trajkov D, Spiroski M. Association between HLA-A, HLA-C and HLA-B Genes and Ankylosing Spondylitisin Macedonian Genesand Population. Maced J Med Sci. 2012 Oct 15; 5(3):263-268. http://dx.doi.org/10.3889 MJMS.1957-5773.2012.0255.

Key words: HLA class I; HLA-B*27; ankylosing spondylitis; disease association; Republic of Macedonia.

Correspondence: Mirko Spiroski, MD, PhD. Institute of Immunobiology and Human Genetics, Faculty of Medicine, 1109 Skopje, PO Box 60 Republic of Macedonia. Phone: +389 23110556 . E-mail: mspiroski@yahoo.com

Received: 12-May-2012; Revised: 14-Aug-2012 Accepted: 20-Aug-2012; Online first: 22-Aug-2012

Copyright: (๑) 2012 Kirijas M. This is an open access article distributed under the terms of the Creative Commons Attribution License, which permits unrestricted use, distribution, and reproduction in any medium, provided the original author and source are credited

Competing Interests: The authors have declared
\end{abstract} that no competing interests exist.

\section{Abstract}

Aim: The aim of this study was to determine the association of HLA-A, $-\mathrm{C}$ and -B genes with ankylosing spondylitis in patients from the Republic of Macedonia.

Material and Methods: This study included 307 subjects ( 250 healthy individuals and 57 patients with ankylosing spondylitis who were diagnosed at the University Clinic of Rheumatology in Skopje). The HLA typing of class 1 (HLA-A, HLA-C and HLA-B) genes was performed using the method of Reverse Line Strip, after isolation of DNK from the blood leucocytes with the standard phenol-chloroforme method. The HLA sub typing of HLA-B*27 was performed with high resolution single-strand polymorphism.

Results: We found negative association between HLA-A*03, HLA-A*24, HLA-C*04, and HLA-B*18, as well as positive association between HLA-C*01, HLA-C*02, and HLA-B*27 group specific alleles and patients with ankylosing spondylitis. Both HLA-B*27:02 and HLA-B*27:05 alleles have shown positive association with ankylosing spondylitis.

Conclusion: Group specific alleles HLA-A*03, HLA-A*24, HLA-C*04, and HLA-B*18 are significantly more frequent in healthy individuals than in patients with ankylosing spondylitis which suggests their protective role. HLA-C*01, HLA-C*02, and HLA-B*27 group specific alleles (HLA-B*27:02 and HLA$B \star 27: 05)$ have strong positive or susceptible association with ankylosing spondylitis.

\section{Introduction}

The Major Histocompatibility Complex (MHC) is the most polymorphic genetic system in humans discovered so far, best known for his central role in histocompatibility and immune regulation and has special clinical role in transplantation of tissues and organs, transfusion reactions, reproduction and some diseases [1]. All vertebrates studied so far have a cluster of genes, called $\mathrm{MHC}$, whose products play role in the recognition and discrimination of self from foreign antigens.
The human MHC, called HLA, is located on chromosome $6 \mathrm{p} 21.31$ and covers a region of about 3.6 Mbp depending on the haplotype [1]. The HLA complex is divided into three regions: class I, II, and III regions as first proposed by Jan Klein in 1977 [2]. Centromeric on the chomosome 6 are the genes for class 2, telomeric the genes for class 1 of $\mathrm{HLA}$, and between them are the genes for HLA class 3 , which encode different proteins like complement factors $\mathrm{C} 4, \mathrm{C} 2$, factor B and TNF-alpha and beta $[3,4]$. 
HLA class 1 molecules have one copy of the two polypeptide chains: heavy chain alpha-polymorphic and light chain beta2 microglobulin-monomorphic. The genes for HLA class 1 code the heavy chains of the six HLA class 1 isoforms HLA-A, -B, -C, -E, -F and -G. The gene who encodes the beta2 microglobulin, the common light chain for all HLA class 1 molecules, is located on chromosome $15[3,4,5]$. The polymorphism of the HLA class 1 molecules (HLA-A, $-B$ and $-C$ ) is due to the difference in the amino acid sequence of the heavy alpha chain. The most of these differences are due to nucleotide substitution in exons 2 and 3 [4]. With the development of new molecular techniques for HLA typing, the number of polymorphisms for each HLA class 1 gene increases.

After the standardization of the methods for serological typing of the HLA class 1 molecule, started the studies that assessed the association of different HLA polymorphisms with certain diseases. In 1973, the first results have shown the association of $H L A-B * 27$ antigen with ankylosing spondylitis, which is one of the strongest associations in the HLA locus [6].

The first associations with diseases were discovered for the antigens of HLA class 1 . But, with the development of techniques for HLA class 2 typing, it was discovered that a lot of diseases show strong association with the alleles of this class. Association between HLA class 1 antigens and hereditary haemochromatosis was found, i.e. association between HLA- A3, HLA-B14 and HLA-A3/B14 antigens with relative risk 90 for the later case. Association between psoriasis and HLA-C6 and chorioretinopaty and HLA-A29 was also found [3].

However, the strongest association for the HLA class 1 antigens was found between the HLA-B*27 antigen and spondiloarthropaties, which include ankylosing spondylitis (AS), Reactive arthritis (Reiter's syndrome), Psoriatic arthritis and Enteropathic arthropathy. Spondiloarthropathies have negative rheumatoid factor, but show strong association with HLA-B*27 alleles. However, these associations vary between different spondiloarthropathies and different ethnic groups [9].

The HLA-B*27 antigen is not the only mediator in the development of spondyloarthropaties. Studies have shown that more than $90 \%$ of the patients with ankylosing spondylitis have the HLA-B*27 antigen, but only small percent of the subjects that carry the HLA$B \star 27$ antigen will develop ankylosing spondylitis [10]. The prevalence of the HLA-B*27 antigen among healthy
Caucasians is between $2 \%$ and $18 \%$ [11]. High prevalence of HLA-B*27 of $10-50 \%$ was found in native Americans, in Africans 4\% and Chinese 4-8\%. Japanese have low prevalence of the HLA-B*27 antigen of $1 \%$ [12]. $H L A-B * 27$ antigen also shows weaker association with the reactive arthritis [13] and spondiloarthropaties associated with psoriasis and inflamatory bowel disease [14]. The prevalence of the HLA-B*27 antigen in patients with reactive arthritis is 30\%-70\% in the studied population of West Europe [13].

The aim of this study was to determine the association of HLA-A, -C and -B genes with ankylosing spondylitis in patients from the Republic of Macedonia.

\section{Material and Methods}

\section{Subjects}

This study involved two groups of subjests: control group and group of patients with ankylosing spondylitis. The control group included 250 voluntary, healthy unrelated individuals with Macedonian origin, age 18-65, without evident signs of disease. The samples were selected from the Macedonian Human DNA Bank at the Institute of Immunobiology and Human Genetics [7]. The group of patients included 57 patients with diagnosed ankylosing spondylitis (AS) at the University Clinic of Rheumatology in Skopje.

\section{Methods}

After obtaining signed informed consent, DNA was isolated from $10 \mathrm{ml}$ peripheral blood sample with EDTA. For isolation a standard phenol-chloroform method was used. The isolated DNA was stored at $4^{\circ} \mathrm{C}$ in the Macedonian Human DNA Bank at the Institute of Immunobiology and Human Genetics.

For analysis of the samples we used the method of Reverse Line Strip (RLS) according to the protocol from the 13th International Histocompatibility Working Group [8]. First the DNA samples were amplified with polymerase chain reaction (PCR) of the exons 2 and 3 of the genes in the HLA-A, -B and -C locus with biotinylated primers. The $P C R$ reaction was performed in total volume of 60 microliters, 30 microliters master mix which contained the primers, dNTP and Taq polymerase, 15 microliters $\mathrm{MgCl}_{2}, 10$ microliters $\mathrm{H}_{2} \mathrm{O}$ and 5 microliters DNA. The termocycler programme used was $95^{\circ} \mathrm{C} 5$ minutes, 30 times $95^{\circ} \mathrm{C} 1$ minute, $62^{\circ} \mathrm{C} 1$ minute and $72^{\circ} \mathrm{C} 1$ minute, and final extension on $4^{\circ} \mathrm{C}$ for indefinite. 
Kirijas et al. Immunoglobulin Classes and Subclasses in Macedonian Elderly People

We used kit for Reverse Line Strip (RLS) from Roche Molecular Systems, USA. Amplified biotinylated DNA material was chemically denaturated and then the separated strands were hybridized with specific oligonucleotide probes immobilized as parallel lines on nitrocellulose strips. We used strips with 56 probes for HLA-A, 85 probes for HLA-B and 35 probes for HLA-C. We used streptavidin-horseradish peroxidase and chromogen substrate to detect the positive lines. To interpret the positive blue lines as genotype we used the software HLA Genotyping Program Roche Molecular System, Inc.

To determine the HLA-B*27 alleles with 4 digits we used a high resolution method for HLA typing, SSP (Sequence Specific Priming). SSP is PCR based technique for amplification of DNA with set of allele specific primers in 96-well plate High Resolution SSP UniTray, PEL-FREEZ. In each well there were specific dried primers for amplification of specific sequence, whose order is given by the manufacturer. The amplification took place in termocycler under these conditions: $96^{\circ} \mathrm{C} 5$ minutes, then $96^{\circ} \mathrm{C} 1$ minute, $70^{\circ} \mathrm{C} 1$ minute, $72^{\circ} \mathrm{C} 1$ minute 5 times, then $96^{\circ} \mathrm{C} 1$ minute, $65^{\circ} \mathrm{C}$ 1 minute, $72^{\circ} \mathrm{C} 1$ minute 21 times and $96^{\circ} \mathrm{C} 1$ minute, $55^{\circ} \mathrm{C} 1$ minute and $72^{\circ} \mathrm{C} 1$ minute 4 times. The PCR products were detected with $2 \%$ agarose gel elctrophoresis with ethidium bromide. For interpretation of the results we used the software UniMatch Plus, Version 3.0, PEL-FREEZ.

\section{Statistical analysis}

All results were compared using the Student ttest and Fishers exact test. $P$ values less than 0.05 were considered significant.

\section{Results}

In the HLA-A locus we found 17 different alleles in both groups of subjects. The most frequent group specific alleles in the group of healthy individuals were HLA-A*02 (31.2\%), HLA-A*24 (14.2\%) and HLA-A*01 $(11.8 \%)$ and in the group of patients with ankylosing spondylitis, HLA-A*02 (39.5\%) and HLA-A*01 (15.8\%). The group specific alleles HLA-A*29 and HLA-A*33 were found only in the group of healthy individuals, but with no statistical significance. We found the group specific alleles HLA-A*03 and HLA-A*24 to be more frequent in the group of healthy individuals, with OR value of and respectively, which can suggest their protective role. The allele HLA-A*69 was found only in the group of patients with ankylosing spondylitis (Table 1 ).
Table 1: Association between HLA-A group specific alleles with ankylosing spondylitis.

\begin{tabular}{|c|c|c|c|c|c|c|c|}
\hline \multirow[t]{2}{*}{$\begin{array}{l}\text { HLA-A } \\
\text { group } \\
\text { specific } \\
\text { allele }\end{array}$} & \multicolumn{2}{|c|}{$\begin{array}{l}\text { Patients with } \\
\text { ankylosing } \\
\text { spondylitis } \\
\text { (114 alleles) }\end{array}$} & \multicolumn{2}{|c|}{$\begin{array}{c}\text { Healthy } \\
\text { unrelated } \\
\text { individuals } \\
\text { (500 alleles) }\end{array}$} & \multirow[t]{2}{*}{ Pearson's P } & \multirow[t]{2}{*}{ OR } & \multirow[t]{2}{*}{$95 \% \mathrm{Cl}$} \\
\hline & $\mathrm{N}$ & $\mathrm{F}$ & $\mathrm{N}$ & $\mathrm{F}$ & & & \\
\hline$\overline{H L A-A^{*} 01}$ & 18 & 0.158 & 59 & 0.118 & 0.246 & 1.401 & $0.791-2.483$ \\
\hline HLA-A $A^{*} 02$ & 45 & 0.395 & 156 & 0.312 & 0.089 & 1.438 & $0.944-2.190$ \\
\hline HLA-A $A^{*} 03$ & 5 & 0.044 & 54 & 0.108 & $0.036^{\star}$ & 0.379 & $0.148-0.970$ \\
\hline HLA-A $A^{\star} 11$ & 11 & 0.096 & 26 & 0.052 & 0.072 & 1.947 & $0.932-4.066$ \\
\hline HLA-A $A^{\star} 23$ & 3 & 0.026 & 15 & 0.030 & 0.833 & 0.874 & $0.249-3.071$ \\
\hline HLA-A $A^{\star} 24$ & 7 & 0.061 & 71 & 0.142 & $0.020^{*}$ & 0.395 & $0.177-0.884$ \\
\hline HLA-A ${ }^{\star} 25$ & 2 & 0.017 & 10 & 0.020 & 0.864 & 0.875 & $0.189-4.049$ \\
\hline HLA-A ${ }^{\star} 26$ & 2 & 0.017 & 20 & 0.040 & 0.244 & 0.429 & $0.099-1.860$ \\
\hline HLA-A $A^{*} 29$ & 0 & 0.000 & 13 & 0.026 & 0.082 & 0.000 & $0.000-\mathrm{NaN}$ \\
\hline HLA-A*30 & 2 & 0.017 & 12 & 0.024 & 0.677 & 0.726 & $0.160-3.291$ \\
\hline HLA-A ${ }^{*} 31$ & 1 & 0.009 & 7 & 0.014 & 0.657 & 0.623 & $0.076-5.117$ \\
\hline HLA-A ${ }^{*} 32$ & 7 & 0.061 & 24 & 0.048 & 0.555 & 1.298 & $0.545-3.090$ \\
\hline HLA-A $A^{*} 33$ & 0 & 0.000 & 3 & 0.006 & 0.407 & 0.000 & $0.000-\mathrm{NaN}$ \\
\hline HLA-A $A^{*} 66$ & 1 & 0.009 & 2 & 0.004 & 0.510 & 2.204 & $0.198-24.514$ \\
\hline HLA-A $A^{\star} 68$ & 4 & 0.035 & 22 & 0.044 & 0.670 & 0.790 & $0.267-2.339$ \\
\hline HLA-A ${ }^{*} 69$ & 2 & 0.017 & 0 & 0.000 & $0.003^{*}$ & $\operatorname{lnf}$ & $\mathrm{NaN}-\ln f$ \\
\hline ? & 4 & 0.035 & 6 & 0.012 & 0.079 & 2.994 & $0.831-10.789$ \\
\hline
\end{tabular}

$\mathrm{N}=$ number of alleles; $\mathrm{F}=$ frequency of alleles; OR, Odds Ratio; $\mathrm{Cl}$, confidence interval; *, statistically significant; Inf, infinity; NaN, cannot be calculated; ?, unknown.

In the HLA-C locus we identified 14 group specific alleles in both groups. The most frequent in the group of healthy individuals were HLA-C*07 (24.6\%), HLA-C*04 (16.0\%) and HLA-C*12 (14.4\%) and in the group of patients with ankylosing spondylitis, HLA-C*07 (16.7\%) and HLA-C*12 (9.6\%). We found negative association between HLA-C*04, as well as positive association between HLA-C*01 and HLA-C*02 and patients with ankylosing spondylitis (Table 2).

In the HLA-B locus we identified 30 group specific alleles in both groups. Most frequent in the group of healthy individuals were HLA-B*51 (14.2\%), HLA-B*35 (13.4\%) and HLA-B*18 (13.0\%) group specific alleles, whereas in the group of patients with ankylosing spondylitis HLA-B*27 (45.6\%) and HLA-B*35 (8.8\%) and HLA-B*51 (7.9\%) were most frequent. The group specific alleles HLA-B*12, HLA-B*13, HLA-B*45, HLA$B \star 56, H L A-B * 58, H L A-B * 73, H L A-B * 78$ and HLA-B*87 were found only in the group of healthy individuals, but

Table 2: Association between HLA-C group specific alleles with ankylosing spondylitis.

\begin{tabular}{|c|c|c|c|c|c|c|c|}
\hline \multirow[t]{2}{*}{$\begin{array}{l}\text { HLA-C group } \\
\text { specific } \\
\text { allele }\end{array}$} & \multicolumn{2}{|c|}{$\begin{array}{l}\text { Patients with ank ylosing } \\
\text { spondylitis } \\
\text { (114 alleles) }\end{array}$} & \multicolumn{2}{|c|}{$\begin{array}{l}\text { Healthy unrelated } \\
\text { individuals } \\
(500 \text { alleles })\end{array}$} & \multirow[t]{2}{*}{ Pearson's $P$} & \multirow[t]{2}{*}{ OR } & \multirow[t]{2}{*}{$95 \% \mathrm{Cl}$} \\
\hline & $\begin{array}{r}\mathrm{N} \\
10\end{array}$ & $F$ & $\mathrm{~N}$ & $\mathrm{~F}$ & & & \\
\hline $\begin{array}{l}\text { HLA-C } \text { C }^{*} 01 \\
\text { HLA-C }{ }^{*} 02\end{array}$ & $\begin{array}{l}10 \\
38\end{array}$ & $\begin{array}{l}0.088 \\
0.333\end{array}$ & $\begin{array}{l}20 \\
42\end{array}$ & $\begin{array}{l}0.040 \\
0.084\end{array}$ & $\begin{array}{l}0.033^{\star} \\
<0.001^{\star}\end{array}$ & $\begin{array}{l}2.308 \\
5.452\end{array}$ & $\begin{array}{l}1.049-5.075 \\
3.302-9.003\end{array}$ \\
\hline HLA-C ${ }^{*} 03$ & 3 & 0.026 & 34 & 0.068 & 0.091 & 0.370 & $0.112-1.228$ \\
\hline HLA-C*04 & 10 & 0.088 & 80 & 0.160 & $0.049^{*}$ & 0.505 & $0.253-1.008$ \\
\hline HLA-C*05 & 4 & 0.035 & 20 & 0.040 & 0.807 & 0.873 & $0.292-2.604$ \\
\hline HLA-C 06 & 4 & 0.035 & 36 & 0.072 & 0.150 & 0.469 & $0.163-1.344$ \\
\hline $\begin{array}{l}\text { HLA-C. } 07 \\
\text { HLA-C } 08\end{array}$ & $\begin{array}{r}19 \\
1\end{array}$ & 0.167 & 123 & 0.246 & 0.070 & 0.613 & $0.360-1.045$ \\
\hline $\begin{array}{l}\text { HLA-C. } 08 \\
\text { HLA-C* } 12\end{array}$ & $\begin{array}{c}1 \\
11\end{array}$ & $\begin{array}{l}0.009 \\
0.096\end{array}$ & $\begin{array}{r}6 \\
72\end{array}$ & 0.0144 & 0.181 & 0.729 & $\begin{array}{l}0.087-6.112 \\
0.325-1241\end{array}$ \\
\hline HLA-C*14 & 4 & 0.035 & 21 & 0.042 & 0.736 & 0.829 & $\begin{array}{l}0.325-1.241 \\
0.279-2.465\end{array}$ \\
\hline HLA-C* 15 & 4 & 0.035 & 35 & 0.070 & 0.168 & 0.483 & $0.168-1.388$ \\
\hline HLA-C*16 & 1 & 0.009 & 4 & 0.008 & & 1.097 & $0.122-9.912$ \\
\hline $\begin{array}{c}\text { HLA-C }{ }^{*} 17 \\
?\end{array}$ & $\begin{array}{l}1 \\
4\end{array}$ & $\begin{array}{l}0.009 \\
0.035\end{array}$ & $\begin{array}{l}7 \\
0\end{array}$ & $\begin{array}{l}0.014 \\
0.000\end{array}$ & $\begin{array}{l}0.657 \\
<0.001^{\star}\end{array}$ & 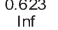 & $\begin{array}{l}0.076-5.117 \\
\text { NaN-inf }\end{array}$ \\
\hline
\end{tabular}

$\mathrm{N}=$ number of alleles; $\mathrm{F}=$ frequency of alleles; OR, Odds Ratio; $\mathrm{Cl}$, confidence interval; *, statistically significant; Inf, infinity; NaN, cannot be calculated; ?, unknown. 
Table 3: Association between HLA-B group specific alleles with ankylosing spondylitis.

\begin{tabular}{|c|c|c|c|c|c|c|c|}
\hline $\begin{array}{l}\text { HLA-B } \\
\text { group } \\
\text { specific } \\
\text { allele }\end{array}$ & \multicolumn{2}{|c|}{$\begin{array}{l}\text { Patients with } \\
\text { ankylosing } \\
\text { spondylitis } \\
\text { (114 alleles) }\end{array}$} & \multicolumn{2}{|c|}{$\begin{array}{c}\text { Healthy } \\
\text { unrelated } \\
\text { individuals } \\
(500 \text { alleles) }\end{array}$} & Pearson's P & OR & $95 \% \mathrm{Cl}$ \\
\hline HLA-B*07 & 3 & 0.026 & 24 & 0.048 & 0.308 & 0.536 & $0.159-1.812$ \\
\hline HLA-B ${ }^{*} 08$ & 4 & 0.035 & 29 & 0.058 & 0.328 & 0.591 & $0.203-1.715$ \\
\hline HLA-B*12 & 0 & 0.000 & 1 & 0.002 & 0.633 & 0.000 & $0.000-\mathrm{NaN}$ \\
\hline HLA-B*13 & 0 & 0.000 & 15 & 0.030 & 0.061 & 0.000 & $0.000-\mathrm{NaN}$ \\
\hline HLA-B*14 & 1 & 0.009 & 5 & 0.010 & 0.904 & 0.876 & $0.101-7.572$ \\
\hline HLA-B*15 & 3 & 0.026 & 14 & 0.028 & 0.921 & 0.938 & $0.265-3.321$ \\
\hline HLA-B*18 & 6 & 0.053 & 65 & 0.130 & $0.020^{*}$ & 0.372 & $0.157-0.881$ \\
\hline HLA-B*27 & 52 & 0.456 & 19 & 0.038 & $0.000^{*}$ & 21.233 & $11.791-38.236$ \\
\hline HLA-B*35 & 10 & 0.088 & 67 & 0.134 & 0.178 & 0.621 & $0.309-1.249$ \\
\hline HLA-B*37 & 1 & 0.009 & 8 & 0.016 & 0.562 & 0.544 & $0.067-4.396$ \\
\hline HLA-B*38 & 2 & 0.018 & 22 & 0.044 & 0.188 & 0.388 & $0.090-1.674$ \\
\hline HLA-B*39 & 2 & 0.018 & 12 & 0.024 & 0.677 & 0.726 & $0.160-3.291$ \\
\hline HLA-B*40 & 3 & 0.026 & 26 & 0.052 & 0.243 & 0.493 & $0.147-1.657$ \\
\hline HLA-B*41 & 1 & 0.009 & 8 & 0.016 & 0.562 & 0.544 & $0.067-4.396$ \\
\hline HLA-B*44 & 5 & 0.044 & 34 & 0.068 & 0.340 & 0.629 & $0.240-1.645$ \\
\hline HLA-B*45 & 0 & 0.000 & 1 & 0.002 & 0.633 & 0.000 & $0.000-\mathrm{NaN}$ \\
\hline HLA-B*47 & 1 & 0.009 & 0 & 0.000 & $0.036^{*}$ & Inf & NaN-Inf. \\
\hline HLA-B*49 & 1 & 0.009 & 10 & 0.020 & 0.415 & 0.434 & $0.055-3.422$ \\
\hline HLA-B*50 & 2 & 0.018 & 3 & 0.006 & 0.216 & 2.958 & $0.489-17.914$ \\
\hline HLA-B*51 & 9 & 0.079 & 71 & 0.142 & 0.071 & 0.518 & $0.251-1.070$ \\
\hline HLA-B*52 & 3 & 0.026 & 14 & 0.028 & 0.921 & 0.938 & $0.284-3.107$ \\
\hline HLA-B*53 & 1 & 0.009 & 5 & 0.010 & 0.904 & 0.876 & $0.101-7.572$ \\
\hline HLA-B*55 & 1 & 0.009 & 22 & 0.044 & 0.074 & 0.192 & $0.026-1.442$ \\
\hline HLA-B*56 & 0 & 0.000 & 1 & 0.002 & 0.633 & 0.000 & $0.000-\mathrm{NaN}$ \\
\hline HLA-B*57 & 3 & 0.026 & 8 & 0.016 & 0.454 & 1.662 & $0.434-6.366$ \\
\hline HLA-B*58 & 0 & 0.000 & 4 & 0.008 & 0.338 & 0.000 & $0.000-\mathrm{NaN}$ \\
\hline HLA-B* 73 & 0 & 0.000 & 1 & 0.002 & 0.633 & 0.000 & $0.000-\mathrm{NaN}$ \\
\hline HLA-B*78 & 0 & 0.000 & 4 & 0.008 & 0.338 & 0.000 & $0.000-\mathrm{NaN}$ \\
\hline HLA-B*87 & 0 & 0.000 & 1 & 0.002 & 0.633 & 0.000 & $0.000-\mathrm{NaN}$ \\
\hline ? & 0 & 0.000 & 6 & 0.012 & 0.240 & 0.000 & $0.000-\mathrm{NaN}$ \\
\hline
\end{tabular}

$\mathrm{N}=$ number of alleles; $\mathrm{F}=$ frequency of alleles; $\mathrm{OR}$, Odds Ratio; $\mathrm{Cl}$, confidence interval; * statistically significant; Inf, infinity; NaN, cannot be calculated; ?, unknown.

with no statistical significance. In addition, we found strong positive association between the group specific $H L A-B * 27$ allele and patients with ankylosing spondylitis, with OR value of 21.233, and negative association between the HLA-B*18 allele and patients with ankylosing spondylitis, OR value 0.372 . HLA-B*47 group specific alleles were found only in the group of patients with ankylosing spondylitis and not in the group of healthy individuals which can suggest their possible association with ankylosing spondylitis (Table 3).

HLA-B*27:02 was found in $27.2 \%$ of the patients

Table 4: Association between HLA-B alleles with ankylosing spondylitis.

\begin{tabular}{ccrrrrrr}
\hline Patients with & $\begin{array}{c}\text { Healthy unrelated } \\
\text { ankylosing } \\
\text { spondylitis } \\
\text { individuals } \\
\text { (114 alleles) }\end{array}$ & $\begin{array}{c}\text { (500 alleles) } \\
\text { HLA-B allele }\end{array}$ & Pearson's P & OR & $95 \% \mathrm{Cl}$ \\
& $\mathrm{N}$ & $\mathrm{F}$ & $\mathrm{N}$ & $\mathrm{F}$ & & & \\
\hline HLA-B*27:02 & 31 & 0.272 & 8 & 0.016 & $<0.001^{*}$ & 22.970 & $10.205-51.702$ \\
HLA-B*27:05 & 21 & 0.184 & 11 & 0.022 & $<0.001^{*}$ & 10.038 & $4.683-21.517$ \\
\hline
\end{tabular}

$\mathrm{N}=$ number of alleles; $\mathrm{F}=$ frequency of alleles; $\mathrm{OR}$, Odds Ratio; $\mathrm{Cl}$, confidence interval; * statistically significant.

with ankylosing spondylitis, whereas HLA-B*27:05 in $18.4 \%$ of them. Both HLA-B*27:02 and HLA-B*27:05 have shown strong positive association with ankylosing spondylitis. The observed Odds-Ratio value for HLA$B * 27: 02$ is 2-fold higher then the one for HLA-B*27:05 (Table 4).

\section{Discussion}

In this study we examined 307 subjects, 250 voluntary, healthy unrelated individuals with Macedonian origin, age 18-65, without evident signs of disease and 57 patients with diagnosed ankylosing spondylitis at the University Clinic of Rheumatology in Skopje. We performed HLA typing in both groups and found that group specific alleles HLA-A*03, HLA-A*24, HLA-C*04, and HLA-B*18 are significantly more frequent in healthy individuals than in patients with ankylosing spondylitis which suggests their protective role. HLA-C*01, HLA$C * 02$, and $H L A-B * 27$ group specific alleles (HLA-B*27:02 and HLA-B*27:05) have strong positive or susceptible association with ankylosing spondylitis.

Harfouch El, et al., 2011 [16] investigated the prevalence of HLA-B*27 and its subtypes associated with ankylosing spondylitis in 50 Syrian patients and 217 unrelated healthy Syrian controls. They found that $1.4 \%$ of the Syrians and $60 \%$ of the patients with ankylosing spondylitis have the HLA-B*27 allele. The most common $H L A-B * 27$ variants in patients were $B * 27: 05$, which was found in $67 \%$ of the patients, followed by $B * 27: 02$ found in $20 \%$ of the patients. HLA-B*27 was identified in all cases with uveitis, peripheral arthritis, and positive family history.

Fernández-Sueiro JL et al., 2004 [17] assessed the prevalence of HLA-B*27 and its subtypes in both the normal population and in patients with ankylosing spondylitis in Galicia, Northwest Spain. The prevalence of HLA-B*27 in the normal population was determined by checking the number of HLA-B*27 positive samples in 308 subjects from different areas of Galicia who had donated organs over a period of 4 years. A total of 106 patients with the diagnosis of ankylosing spondylitis, according to the modified New York clinical criteria for definitive ankylosing spondylitis, were collected from three very representative areas of Galicia. They found that the prevalence of HLA-B ${ }^{\star} 27$ in organ donors was 9.34\% [B*27:05 (79.5\%), $B * 27: 02$ (18\%) and $B * 27: 08$ $(2.5 \%)]$ and $H L A-B * 27$ was found in $94.3 \%$ of the patients with ankylosing spondylitis with the subtypes $B * 27: 05$ $(88 \%)$ and $B \star 27: 02$ (12\%) associated with ankylosing spondylitis.

Joshi R et al., 2012 [18] wanted to determine whether familial ankylosing spondylitis cases have a higher genetic load of different susceptibility loci. They investigated two groups of patients with AS, first group of 312 patients who had first-degree relatives (FDRs) with ankylosing spondylitis (familial) and second group 
of 190 patients who had no FDRs with ankylosing spondylitis or spondylarthritis (sporadic). All patients and affected FDRs fulfilled the modified New York criteria for ankylosing spondylitis. They found that HLA-B*27 was significantly more prevalent in familial than sporadic cases of ankylosing spondylitis and the ankylosing spondylitis risk allele at chromosome 21q22 intergenic region showed a trend toward higher frequency in the multiplex cases. The frequency of the recently described non-major histocompatibility complex susceptibility loci did not markedly differ between the sporadic and familial cases of ankylosing spondylitis.

Beside HLA-B*27, different MHC markers are being associated with ankylosing spondylitis. Group of authors investigated the potential association of major histocompatibility complex (MHC) markers other than HLA-B*27 with ankylosing spondylitis. They found HLA markers and linkage disequilibrium blocks near HLADPA1 and HLA-DPB1 that were statistically associated with ankylosing spondylitis [19]. We published high resolution sequencing based method for direct HLADRB1 typing in the healthy Macedonians which can be used as a control for future association studies of MHC class II alleles with ankylosing spondylitis [20]. Our results with rheumatoid arthritis showed susceptible association for four cytokine alleles, six cytokine genotypes, one haplotype, and four combinations of haplotypes, while protective associations were found for four cytokine alleles, three cytokine genotypes, three haplotypes, and only one combination of haplotypes. These results suggest that cytokine gene polymorphisms might be significantly associated and affect host susceptibility and/or resistance to rheumatoid arthritis in Macedonians [21].

Authors examined 262 persons (122 patients with ankylosing spondylitis and 140 healthy controls) to determine the frequency of I/D polymorphism genotypes of angiotensin converting enzyme gene. They found that the DD genotype of the angiotensin converting enzyme gene is associated with ocular involvement and involvement of the sacroiliac joint in patients with ankylosing spondylitis [22].

Certain authors examined whether KIR genes contribute to the pathogenesis of ankylosing spondylitis in Chinese populations [23]. They found that the frequency of the activator receptor KIR3DS1 gene in the ankylosing spondylitis group was significantly increased compared to the controls and thus may play, in addition to HLA$B * 27$, an independent role in the pathogenesis of ankylosing spondylitis.
The prominent role of $H L A-B * 27$ in the development of ankylosing spondylitis was confirmed by many researchers. Reveille JD., 2006 [15] in his review says that there have been over 31 variants of HLA-B*27 identified so far, which have evolved from the original HLA-B*27 allele ( $B * 27: 05)$ along three geographic lines. $H L A-B * 27: 05$ and $B * 27: 02$ are the primary subtypes in Caucasians with spondylitis, and $B * 27: 04$ and $B * 27: 07$ are the primary subtypes in Asians. HLA-B*27:06 and $B \star 27: 09$ are not disease associated.

In the two groups of subjects, we investigated, we found only two alleles of the HLA-B*27 group specific alleles, HLA-B*27:02 and HLA-B*27:05. In the group of patients with ankylosing spondylitis, the allele frequency of the HLA-B*27 allele was $45.6 \%$, and HLA-B*27:02 and HLA-B ${ }^{\star} 27: 05$ had frequencies of $27.2 \%$ and $18.4 \%$, respectively. $\mathrm{HLA}-\mathrm{B} * 27$ group specific allele was present only in $3.8 \%$ of the healthy individuals. HLA-B*27 is found only in Caucasians and dominates in Jews, and in populations in Algeria and Tunisia. The HLA-B*27:04 allele shows strong association with spondyloarthropaties, and is dominant in Chinese and Japanese. HLA-B*27:07 subtype is rare and is described in Asian populations (India, China and Thailand) and is associated with spondyloarthropaties [24].

As a conclusion, group specific alleles HLA$A * 03, H L A-A * 24, H L A-C * 04$, and HLA-B*18 are significantly more frequent in healthy individuals than in patients with ankylosing spondylitis which suggests their protective role, while HLA-C*01, HLA-C*02, and HLA$B * 27$ group specific alleles (HLA-B*27:02 and HLA$B \star 27: 05)$ have strong positive or susceptible association with ankylosing spondylitis.

\section{Acknowledgement}

This work was supported in part from the ICGEB Collaborative Research Programme (Project CRP/ MAC03-01, "Ambiguities resolution of HLA genotypes in Macedonian population"), Trieste, Italy. Special thanks go to Elena Cvetkovska for sample collection, technical support, and laboratory direction.

\section{References}

1. Dorak MT. Major Histocompatibility Complex. [Online] http:/ /www.dorak.info/mhc/mhc.html,2011.

2. Klein J. Evolution and function of the major histocompatibility complex: facts and speculations. In: Gotze D, ed. The Major 
Histocompatibility System in Man and Animals, New York: Springer-Verlag, 1976: 339-378.

3. Marsh SGE, Parham P, Barber LD. The HLA FactsBook. Academic Press, London, UK, 2000.

4. Gruen JR, Weissman SM. Evolving views of the major histocompatibility complex. Blood. 1997; 90: 4252-4265.

5. Rhodes DA, Trowsdale J. Genetics and molecular genetics of the MHC. Rev Immunogenet. 1999;1:21-31.

6. Brewerton DA, Caffrey M, Hart FD, James DCO, Nichols A, Sturrock RD: Ankylosing spondylitis and HL-A27. Lancet. 1973;1(7809):904-7.

7. Spiroski M, Arsov T, Petlichkovski A, Strezova A, Trajkov D, Efinska-Mladenovska O, Zaharieva E. Case Study: Macedonian Human DNA Bank (hDNAMKD) as a source for public health Genetics. In: Health Determinants in the Scope of New Public Health. Ed. by Georgieva L, Burazeri G. Hans Jacobs Company: Sofia, 2005:33-44.

8. Saiki RK, Walsh PS, Levenson $\mathrm{CH}$, Erlich HA. Genetic analysis of amplified DNA with immobilized sequence-specific oligonucleotide probes. Proc Natl Acad Sci U S A. 1989;86(16):6230-4.

9. McMichael A, Bowness P. HLA-B27: natural function and pathogenic role in spondyloarthritis. Arthritis Res. 2002;4: 153158.

10. Brown MA, Pile KD, Kennedy LG, Calin A, Darke C, Bell J, Wordsworth BP, Cornelis F. HLA class I associations of ankylosing spondylitis in the white population in the United Kingdom. Ann Rheum Dis. 1996;55:268-270.

11. Armas BJ, Santos M, Peixoto MJ, Couto RA, Garrett F. HLA and Spondyloarthritis. Int J Hum Genet. 2004;4(2):125135.

12. Chen J, Hou TY, Liu FC, Chen $\mathrm{CH}$, Lai JH, Chang DM, Kuo SY. The prevalence of HLA-B ${ }^{\star 2} 2$ subtypes in ankylosing spondylitis patients. J Rheumatol R.O.C. 2007;21:52-56.

13. Colmegna I, Cuchacovich R, Espinoza LR. HLA-B27associated reactive arthritis: Patogenic and clinical consideration. Clinical Microbiology Reviews. 2004; 17(2):348369

14. Orchard TR, Thiyagaraja S, Welsh KI, Wordsworth BP, Hill Gaston JS, Jewell DP. Clinical phenotype is related to HLA genotype in the peripheral arthropathies of inflammatory bowel disease. Gastroenterology. 2000;118:274-278.
15. Reveille JD. Major histocompatibility genes and ankylosing spondylitis. Best Pract Res Clin Rheumatol. 2006;20(3):6019.

16. Harfouch El, Al-Cheikh SA. HLA-B*27 and its subtypes in Syrian patients with ankylosing spondylitis.Saudi Med J. 2011;32(4):364-8.

17. Fernández-Sueiro JL, Alonso C, Blanco FJ, Rodrí guezGómez M, Galdo F, González-Gay MA. Prevalence of HLA$B \star 27$ and subtypes of HLA-B*27 associated with ankylosing spondylitis in Galicia, Spain.Clin Exp Rheumatol. 2004;22(4):465-8.

18. Joshi R, Reveille JD, Brown MA, Weisman MH, Ward MM, Gensler LS, Wordsworth BP, Evans DM, Assassi S. Is there a higher genetic load of susceptibility loci in familial ankylosing spondylitis? Arthritis Care Res (Hoboken). 2012;64(5):780-4.

19. Dí az-Peña R, Aransay AM, Bruges-Armas J, LópezVázquez A, Rodrí guez-Ezpeleta N, Mendibil I, Sánchez A, Torre-Alonso JC, Bettencourt BF, Mulero J, Collantes E, LópezLarrea C. Fine mapping of a major histocompatibility complex in ankylosing spondylitis: association of the HLA-DPA1 and HLA-DPB1 regions. Arthritis Rheum. 2011;63(11):3305-12.

20. Petlichkovski A, Efinska-Mladenovska O, Trajkov D, Arsov T, Strezova A, Spiroski M. High-resolution typing of HLA-DRB1 locus in the Macedonian population. Tissue Antigens. 2004;64(4):486-91.

21. Trajkov D, Mishevska-Perchinkova S, KaradzovaStojanoska A, Petlichkovski A, Strezova A, Spiroski M. Association of 22 cytokine gene polymorphisms with rheumatoid arthritis in population of ethnic Macedonians. Clin Rheumatol. 2009;28(11):1291-300.

22. Inanýr A, Yigit S, Tural S, Ozturk SD, Akkanet S, Habiboðlu A. Significant association between insertion/deletion polymorphism of the angiotensin-convertig enzyme gene and ankylosing spondylitis. Mol Vis. 2012;18:2107-13.

23. Wang S, Li G, Ge R, Duan Z, Zeng Z, Zhang T, Gao J, Yang T, Liu S, Wu S, Fan D, Xu S, Xu J, Zhang L, Shuai Z, Ye $D$, Zou Y, Pan F. Association of KIR genotype with susceptibility to HLA-B27-positive ankylosing spondylitis. Mod Rheumatol. 2012 Jun 29. [Epub ahead of print].

24. Lopez-Larrea C, Sujirachato $\mathrm{K}$, Mehr N, Chiewsilp P, Isarangkura $D$, Kanga $U$, Dominguez O, Coto E, Pena M, Setien F, Gonzalez-Roces S: HLA-B*27 subtypes in Asian patients with ankylosing spondylitis. Evidence for new associations. Tissue Antigens. 1995;45:169-176. 